\title{
Preliminary studies on productivity of white Pleurotus eryngii isolates in protected cultivation
}

\author{
Gian Luigi Rana, ${ }^{1}$ Daniele Sisto,, Stefania Mirela Mang, ${ }^{1}$ Vincenzo Candido ${ }^{3}$ \\ ${ }^{1}$ Dipartimento di Scienze, Università della Basilicata, Potenza; ${ }^{2}$ Dipartimento di Biologia e \\ Patologia Vegetale, Università di Bari Aldo Moro, Bari; ${ }^{3}$ Scuola di Scienze Agrarie, Forestali, \\ Alimentari ed Ambientali, Università della Basilicata, Potenza, Italy
}

\begin{abstract}
Four isolates of Pleurotus eryngii species-complex, originating from different basidiomata growing in a mountainous area of the Basilicata region (southern Italy) and characterized by white pileus cuticle (Wh A, Wh B, Wh C, and Wh D) were compared, in artificial cultivation conditions, to other isolates of the same mushroom with beige ( $\mathrm{Be} 3, \mathrm{Be} 5)$ or brown cap $(\mathrm{Br} 1, \mathrm{Br} 2)$ originating from the same area of the former or selected among the commercial ones (Com 142 and Com 164) in order to evaluate their productivity and morphological features. The experiments were carried out in a greenhouse belonging to the Faculty of Agriculture, University of Bari Aldo Moro, in autumn winter $2010-2011$, using substrate bags well colonized by $P$. eryngii mycelium and kept at $4-6^{\circ} \mathrm{C}$ for 5 months. Wh A and Wh D and, less significantly, Wh C, Be 5 and Com 142, produced a fresh basidioma yield significantly higher than the five other tested isolates (Wh B, Be 3, Br 1, Br 2 and Com 164). Only Com 142 produced the basidiomata of medium and maximum size significantly heavier and with larger pileus diameter than other tested isolates. Com 142 also resulted significantly different, for the basidiomata number/substrate bag, from the white pileus cuticle isolates except for Wh B. All tested iso-
\end{abstract}

Correspondence: Vincenzo Candido, Scuola di Scienze Agrarie, Forestali, Alimentari ed Ambientali, Università della Basilicata, via dell'Ateneo Lucano 10,85100 Potenza, Italy.

Tel. +39.0971 .205371 - Fax: +39.0971 .205378 .

E-mail: vincenzo.candido@unibas.it

Key words: cultivation, edible fungi, Pleurotus eryngii, white pileus cuticle.

Acknowledgments: many thanks are expressed to "MICOTEC s.r.l.- Società Agricola" located in Gravina-Bari in Puglia region for substrate bags preparation.

Received for publication: 14 November 2012.

Revision received: 31 January 2013.

Accepted for publication: 4 February 2013.

CC Copyright G.L. Rana et al., 2013

Licensee PAGEPress, Italy

Italian Journal of Agronomy 2013; 8:e6

doi:10.4081/ija.2013.e6

This article is distributed under the terms of the Creative Commons Attribution Noncommercial License (by-nc 3.0) which permits any noncommercial use, distribution, and reproduction in any medium, provided the original author(s) and source are credited. lates concentrated almost all (90-95\%) of the sporophore yield in the first basidioma flush. No significant differences were found among all tested $P$. eryngii isolates in terms of yield earliness.

\section{Introduction}

Cardoncello mushroom [Pleurotus eryngii (DC.: Fr.) Quél.] (Fungi, Dikarya, Basidiomycota, Agaricomycotina, Agaricomycetes, Agaricales, Pleurotaceae) (Hibbett et al., 2007), thank to its excellent organoleptic qualities, was and still is, either in Italy or abroad, the object of several studies aimed to cast light not only on morphological and molecular aspects related to taxonomy (De Gioia et al., 2005; Mang and Figliuolo 2010; Zervakis and Balis, 1996; Zervakis and Venturella, 1998; Venturella et al., 2000, 2002) but also on productivity and mycopathology (Camele et al., 2010; Ferri, 1985; Ferri et al., 2007; Fermor, 1986; Fletcher et al., 1989; Iacobellis, 2011; Iacobellis and Lavermicocca, 1990; Iacobellis and Lo Cantore, 1997, 1998; AA.VV., $1998,2000)$. To elucidate the phylogenetic relations among the different taxa of $P$. eryngii species-complex molecular analysis were accomplished (Mang and Figliuolo, 2010, Rodrigues Estrada et al., 2010) through gene isolation and cloning, DNA sequencing and spontaneous mutation analysis, on several cardoncello mushroom isolates from different geographical areas. The former authors showed that three clusters exist at botanical variety level: Chinese isolates of $P$. eryngii var. nebrodensis, Sicilian isolates of the same variety and $P$. eryngii var. eryngii-ferulae (isolates from Puglia, Sardegna, Basilicata and Sicilia). Similar results were reported by Rodrigues Estrada et al. (2010) who evidenced the presence of four clusters in the $P$. eryngii species-complex: i) P. eryngii var. ferulae, ii) P. eryngii var. eryngii, ii) P. eryngii var. elaeoselini and iv) P. eryngii var. nebrodensis. Under protected cultivation, isolates of the last variety produce, independently of the geographical origin, relatively few large sized basidiomata of white colour, non gregarious and sustained by an eccentric and robust stipe. P. eryngii vars eryngii and ferulae sporophores are much more variable in pileus cuticle colour (white, beige, brown), shape and size, almost always show a gregarious growth in families and sometime have a symmetric stipe.

Cardoncello mushrooms with white cap cuticle are includable into the $P$. eryngii species-complex and are morphologically different from P. eryngii var. nebrodensis originated from Sicilia or China (Venturella, 2000). Venturella et al. (2000), based on macro- and microscopic differences and on the plant which they are associated, Elaeoselinum asclepium (L.) Bertol. subsp. asclepium, included them into a new variety named $P$. eryngii var. elaeoselini.

Some white cardoncello mushroom basidiomata growing close to Eryngium campestre L. and intermingled with sporophores of the 
same fungus with cap cuticle of beige-maroon colour were found in Basilicata in autumn 2009. Because, so far, only isolates of $P$. eryngii with beige or brown cap cuticle had been subjected to protected cultivation experiments (Marras and Sisto, 1998; Sisto et al., 1998; De Gioia et al., 2007; Ferri et al., 2007), it seemed worthwhile to isolate the dycariotic mycelium from some of the above white sporophores and cultivate it in a comparative trial with the following main aims: i) verify if white pileus cuticle feature could be maintained under protected conditions; ii) evaluate the productivity and relative predisposition to lobes and warts of the white pileus isolates in respect of other with beige or brown cap cuticle.
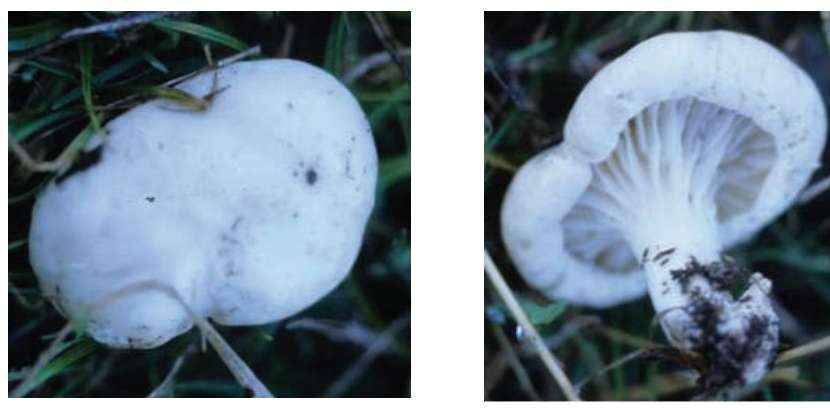

Figure 1. Pileus cuticle colour and gills of the original Pleurotus eryngii Wh A basidioma in nature.

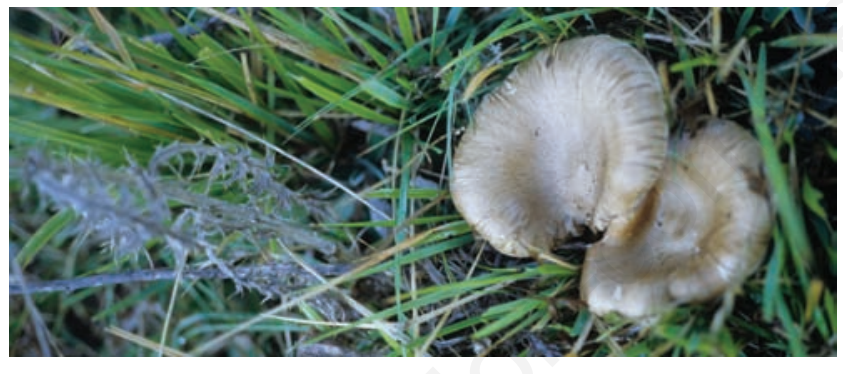

Figure 2. Pileus cuticle colour of the original Pleurotus eryngii Be 3 basidiomata in nature.

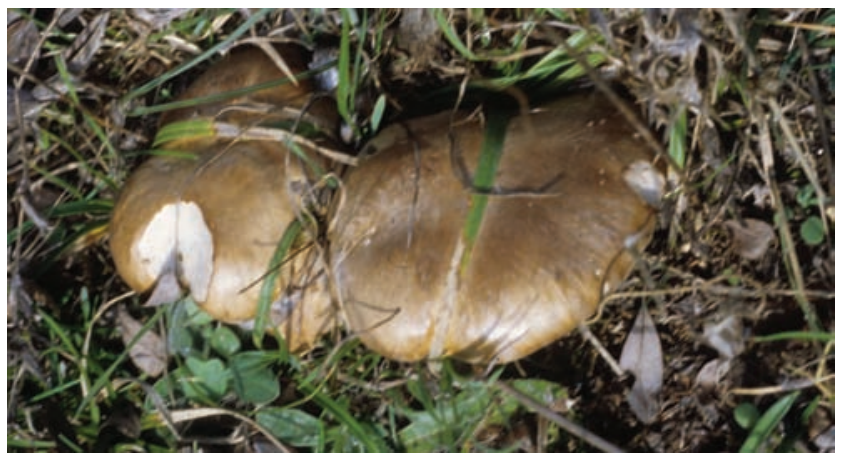

Figure 3. Pileus cuticle colour of the original Pleurotus eryngii $\mathrm{Br}$ 1 basiomata in nature.

\section{Materials and methods}

As Table 1 and Figures 1-5 show, the number, type and origin of cardoncello mushroom isolates investigated in this study are the following: i) four, with white pileus cuticle (hereafter referred as Wh A, Wh B, Wh C, and Wh D) were obtained from as many basidiomata originally found in a mountainous area of Basilicata (1200 m asl) kept as a sheep meadow and located, toward East, at 2-3 km far from La Potentissima locality (Calvello, Potenza, southern Italy); ii) two, with beige cap cuticle (Be 3 and Be 5) derived from sporophores found in Muro Lucano (Potenza province) ter-

Table 1. Geographic origin of Pleurotus eryngii tested isolates and cuticle colour of their respective basidiomata found in nature.

\begin{tabular}{llc} 
Isolate & \multicolumn{1}{c}{ Origin } & $\begin{array}{c}\text { Basidiomata pileus } \\
\text { cuticle colour }\end{array}$ \\
Wh A & Basilicata (Calvello, Potenza) & White \\
Wh B & Basilicata (Calvello, Potenza) & White \\
\hline Wh C & Basilicata (Calvello, Potenza) & White \\
Wh D & Basilicata (Calvello, Potenza) & White \\
\hline Be 3 & Basilicata (Muro Lucano, Potenza) & Beige \\
Be 5 & Basilicata (Muro Lucano, Potenza) & Beige \\
\hline Br 1 & Basilicata (Calvello, Potenza) & Brown \\
Br 2 & Basilicata (Calvello, Potenza) & Brown \\
\hline Com 142 & Puglia (Altamura, Bari) & Brown \\
Com 164 & Puglia (Andria, Bari) & Beige with brown stripes
\end{tabular}

Wh, white pileus cuticle; Be, beige cap; Br, brown cap; Com, commercial.

Table 2. Productive and morphological traits and alterations evaluated on tested isolates of Pleurotus eryngii.

\section{Morphological features and abnormalties}

Pileus cuticle colour

Harvest earliness ${ }^{\circ}$

Total basidioma yield ( $\mathrm{g} \mathrm{kg}^{-1}$ substrate)

Total basidioma number/substrate bag

Number of basidiomata with pileus diameter $>3 \mathrm{~cm}$

Number of small basidiomata (pileus diameter $<3 \mathrm{~cm}$ )/substrate bag

Weight of the medium sized basidioma (WMedSB)

Weight of the maximum sized basidioma (WMaxSB)

Pileus diameter of the medium sized basidioma (PDMedSB)

Pileus diameter of the maximum sized basidioma (PDMaxSB)

Gill decurrence along the maximum sized basidioma stipe (GDMaxSBS)

Spore print colour

Height of the maximum sized basidioma (HMaxSB)

Stipe length of the medium sized basidioma (SLMedSB)

Stipe length of the maximum sized basidioma (SLMaxSB)

Stipe diameter of the medium sized basidioma (SDMedSB)

Stipe diameter of maximum sized basidioma (SDMaxSB)

Lobes on cap margin ${ }^{\#}$

Warts number on cap ${ }^{\#}$

${ }^{\circ}$ Number of days between the trial beginning and the first and unique basidioma harvest; ${ }^{\sharp}$ Lobe and wart occurrence was registered using the following numerical severity scale: $0=$ absence of alteration; $0.5=1$ 3 lobes or warts/cap; $1=4-10$ lobes or warts/cap; $2=$ more than 10 lobes or warts/cap. 
ritory; iii) two, with brown or maroon pileus cuticle ( $\mathrm{Br} 1$ and $\mathrm{Br} 2)$ came from basidiomata growing in the same area of the white cardoncello sporophores; iv) two (Com 142 with brown, sometime finely dotted pileus cuticle and Com 164 with beige, brown-striped pileus) were commercial isolates maintained as pure cultures on potato-dextrose-agar (PDA) in the mycological collection of the second author's department. All the above $P$. eryngii isolates were associated in nature with $E$. campestre.

Wh A, Wh B, Wh C, Wh D, Be 3, Be 5, Br 1 and Br 2 were at first isolated in vitro on PDA containing 30 and $25 \mathrm{mg} / \mathrm{L}$ of streptomycin and ampicillin, respectively. Small pieces of three weeks old pure cultures, successively prepared on PDA for all $P$. eryngii isolates under trial, were used to inoculate sterile woody toothpicks imbibed with a $5 \%$ sucrose water solution. Couples of these last, when completely colonized by $P$. eryngii mycelium, were used to inoculate, following Ferri's technique (1986), single $3.5 \mathrm{~kg}$ sterile standard substrate bags for the basidiomycete cultivation (Sisto et al., 1998). After 80 days of incubation at about $25^{\circ} \mathrm{C}$, on April $20^{\text {th }} 2010$, the same bags, well invaded by cardoncello mycelium, were transferred in a cold room $\left(4-6^{\circ} \mathrm{C}\right)$ and there kept for the following five months. This was done for the following reasons: i) the high temperatures commonly registered in Puglia in spring inhibit the normal growth of the fungus; ii) previous knowledge that a long refrigeration time period generally stimulates cardoncello mush-

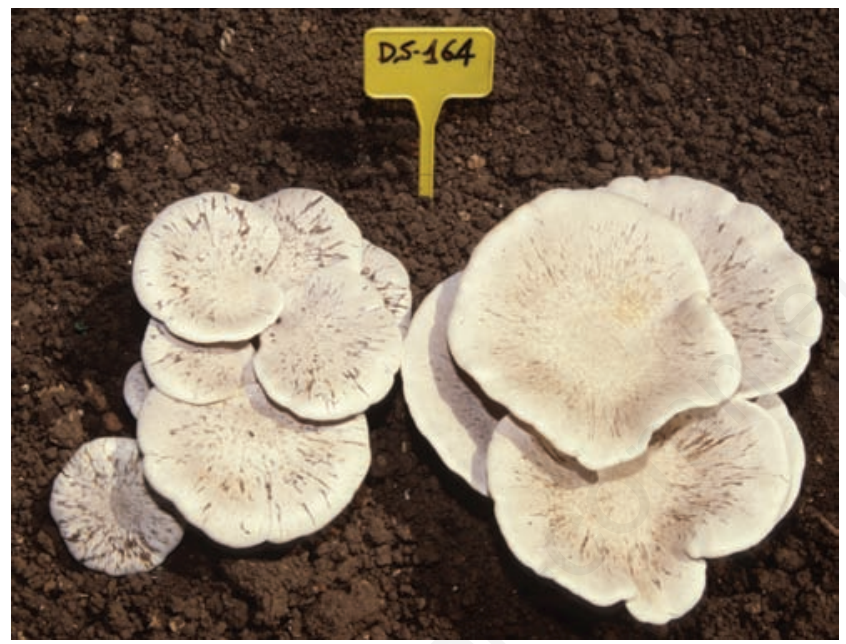

Figure 4. Pileus cuticle colour of Pleurotus eryngii Com 164 isolate.

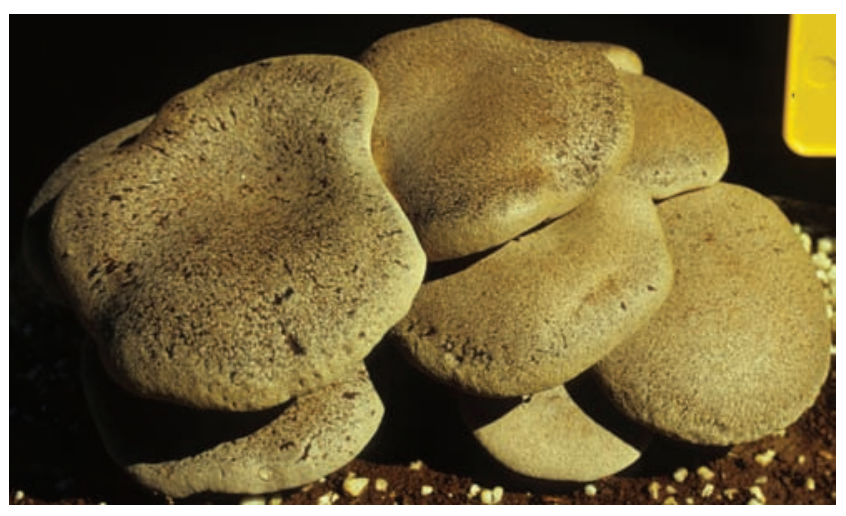

Figure 5. Pileus cuticle colour of Pleurotus eryngii Com 142 isolate. room to produce $90-95 \%$ of yield in the first basidiomata flush (Mario Castelluccio-ITALMIK0-Senise, Potenza, personal communication; Rana and Sisto, unpublished data, 2007). Substrate bags were then put in cultivation in a greenhouse of the Agricultural Experimental Farm, belonging to University of Bari Aldo Moro, located in Valenzano (Bari, Italy). The greenhouse was furnished of a black net overshadowing at $75 \%$ on the roof, an insect-proof white net protecting the lateral windows and a cement floor. Six bags of substrate for each isolate of $P$. eryngii were arranged on the greenhouse floor according to a randomized block with three replicates experimental design. Each experimental unit was formed by two substrate bags. The same were deprived of the upper envelope portion, covered with $1-2 \mathrm{~cm}$ of sterile soil at $\mathrm{pH} 6.5$ and initially wetted with $300-350 \mathrm{cc}^{3}$ of tap water. Trial started on October $8^{\text {th }} 2010$. Substrate bags were carefully watered throughout cultivation period avoiding oversoaking. The numerical data registered after basiodiomata harvest for the productive and morphological traits as well as for the alterations severity are listed in Table 2. Substrate bags were kept under observation for eventual further basidioma production until February $20^{\text {th }}$ 2011. Collected data were subjected to ANOVA procedure separating mean values with Student-NewmanKeuls' test.

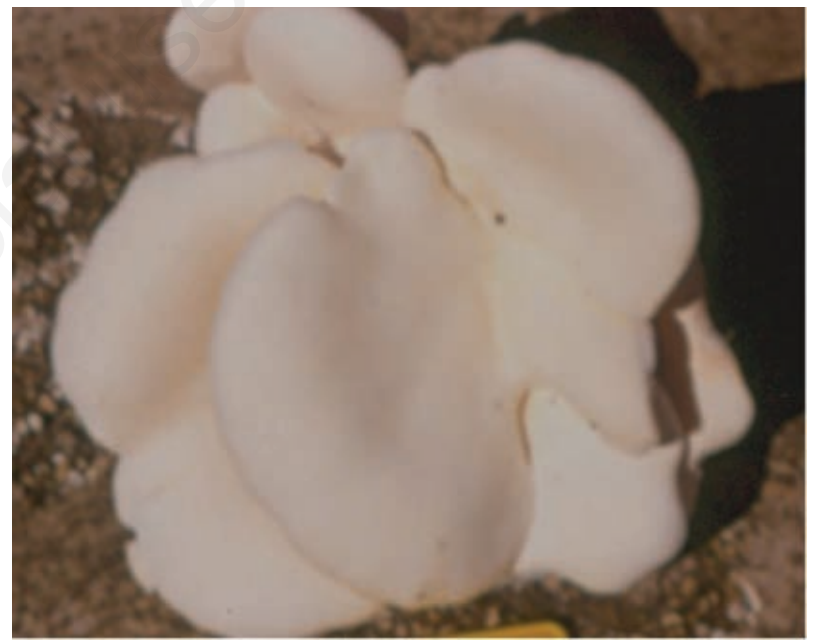

Figure 6. Close up of basidioma cuticle colour of Pleurotus eryngii Wh A isolate under protected cultivation.

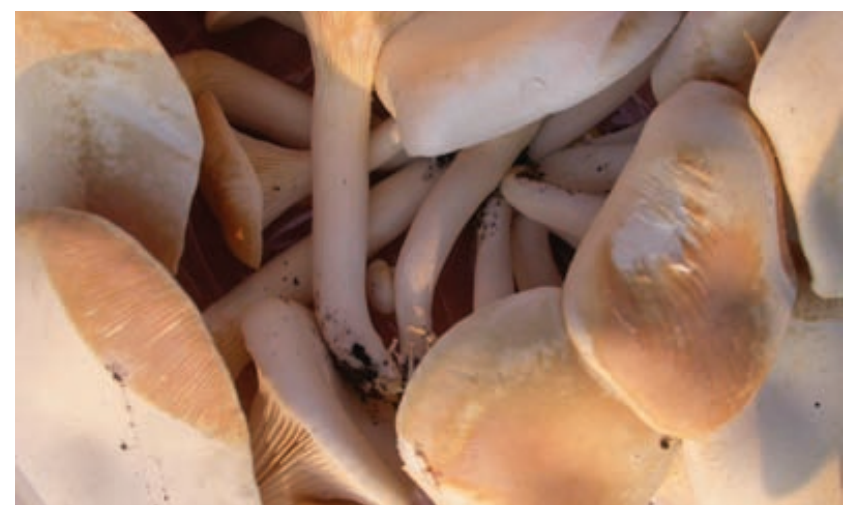

Figure 7. White pileus cuticle and creamy spore print of Pleurotus eryngii Wh $B$ isolate under protected cultivation. 


\section{Results}

The original sporophore cap cuticle colour displayed some minor changes in cultivation under protected conditions. In particular, Wh C and Wh D and, in less extent, Wh A (Figure 6), produced sporophores with isabelline cap cuticle colour that was particularly evident in pileus disk area. Only Wh B remained completely white (Figure 7). On opposite, $\mathrm{Br} 1$ and $\mathrm{Br} 2$ and $\mathrm{Be} 5$ produced basidiomata with pileus surface less colored than in nature. All the white tested isolated gave a spore print of beige-creamy color (Figure 7) whereas the brown and beige ones were characterized by a white spore print.

All the $P$. eryngii tested isolates behaved in the same manner for earliness. In fact, they produced $90-95 \%$ of their basidioma yield in the first, unique and economically relevant basidioma flush that occurred on October $30^{\text {th }} 2010$, i.e. 22 days after cultivation beginning (Table 3 ). None of tested isolates had a second significant basidoma flush. So the relative yield was not considered for data analysis. Marked and significant differences were vice versa noticed in yield level. In fact, Wh A, Wh $\mathrm{C}$ and Wh D produced, on average, $326 \mathrm{~g} \mathrm{~kg}^{-1}$ substrate and did not significantly differentiate from each other. Wh B produced $265 \mathrm{~g} \mathrm{~kg}^{-1}$ substrate, resulting clearly less productive than Wh A and Wh D. Be 5 and Com 142 produced a basidioma yield not significantly different from those of Wh A, Wh C and Wh D whereas Br 1 behaved as Wh B. The less productive isolates resulted $\mathrm{Be} 3$ and $\mathrm{Br} 2$, with an average yield of only
$238 \mathrm{~g} \mathrm{~kg}^{-1}$ substrate, and Com 164 that reached $262 \mathrm{~g} \mathrm{~kg}^{-1}$ substrate. The total basidioma number/substrate bag, for the white pileus isolates, varied from a maximum value of 35.4 in Wh $\mathrm{C}$ to a minimum of 21.1 in Wh B. Intermediate values were reached by Wh A and Wh B with 29.0 and 27.7, respectively. All other isolates originating from Basilicata produced an average basidioma number not significantly different from Wh B, i.e. 15.7. Finally, Com 164 and Com 142 produced 16.4 and 6.5 sporophores/substrate bag, respectively (Table 3 ). As it can be drawn from Table 4, Wh C distinguished itself producing the major number (i.e. 5.3) of small basidiomata per substrate bag whereas $\mathrm{Br} 2$ and Com 142 produced an average of 0.6 small sporophores/bag. The other tested isolates, except for Wh D which produced 4.5 small basidiomata per substrate bag, gave a 1.9 medium value for the same trait without any significant difference. Com 142 produced the higher weight of the medium sized basidioma (WMedSB) (183.7 g) followed by Br 2 and Be 5 that reached for the same trait 81.3 and $74.5 \mathrm{~g}$, respectively. The lowest value ( $37.4 \mathrm{~g}$ ) was registered for Wh B. Values registered, by the other tested isolates were not significantly different from those of $\mathrm{Br} 2$ and Be 5 (Table 4).

Com 142 reached the higher weight of the maximum sized basidioma (WMaxSB) (390.5 g), followed, in decreasing sense, by Be 3 and $\mathrm{Br} 2$ with 254.1 and $183.2 \mathrm{~g}$, respectively; all the other tested cardoncello mushroom isolates showed values not significantly different and ranging from 164.1 to $78.8 \mathrm{~g}$ (Table 4). Pileus diameter of the medium sized basidioma (PDMedSB) reached the maximum value (14.6) $\mathrm{cm}$ in Com 142 , followed by Br 1 and $\mathrm{Br} 2(10.6 \mathrm{~cm}$, on average) and, finally, by Wh

Table 3. Production earliness, total yield and basidiomata number recorded on the ten tested isolates of Pleurotus eryngii.

\begin{tabular}{|c|c|c|c|}
\hline Isolate & Earliness (days) & Yield ( $\mathrm{g} \mathrm{kg}^{-1}$ substrate) & Basidiomata (number/substrate bag) \\
\hline Wh A & $22.0^{\mathrm{a}}$ & $335.5^{\mathrm{a}}$ & $29.0^{\mathrm{ab}}$ \\
\hline Wh B & $22.0^{\mathrm{a}}$ & $265.4^{\mathrm{bc}}$ & $21.1^{\text {ad }}$ \\
\hline Wh C & $22.7^{\mathrm{a}}$ & $319.8^{a b}$ & $35.4^{\mathrm{a}}$ \\
\hline Wh D & $22.0^{\mathrm{a}}$ & $323.2^{\mathrm{a}}$ & $27.7^{\mathrm{ab}}$ \\
\hline Be 3 & $22.0^{\mathrm{a}}$ & $244.7^{c}$ & $12.3^{\mathrm{cd}}$ \\
\hline Be 5 & $22.7^{a}$ & $287.5^{\mathrm{ac}}$ & $23.2^{\mathrm{ac}}$ \\
\hline Br 1 & $22.0^{\mathrm{a}}$ & $266.4^{b c}$ & $18.7^{\mathrm{bd}}$ \\
\hline $\operatorname{Br} 2$ & $22.0^{\mathrm{a}}$ & $232.9^{c}$ & $10.6^{\mathrm{cd}}$ \\
\hline Com 142 & $22.0^{\mathrm{a}}$ & $281.6^{\mathrm{ac}}$ & $6.5^{\mathrm{d}}$ \\
\hline Com 164 & $22.0^{\mathrm{a}}$ & $262.7^{\mathrm{c}}$ & $16.4^{\text {bd }}$ \\
\hline
\end{tabular}

Table 4. Average values of number of small basidiomata/substrate bag and weight and pileus diameter of the medium and maximum sized basidioma of Pleurotus eryngii tested isolates.

\begin{tabular}{|c|c|c|c|c|c|}
\hline Isolate & $\begin{array}{c}\text { Small basidiomata } \\
\text { number/substrate bag }\end{array}$ & $\begin{array}{r}\text { Medium size } \\
\text { pileu }\end{array}$ & $\begin{array}{l}\text { weight (g) } \\
\mathrm{cm} \text { ) }\end{array}$ & $\begin{array}{r}\text { Maximum } s \\
\text { pile }\end{array}$ & $\begin{array}{l}\text { weight (g) } \\
\mathrm{cm} \text { ) }\end{array}$ \\
\hline Wh A & $1.2^{\mathrm{cd}}$ & $50.2^{\mathrm{bc}}$ & $8.6^{\mathrm{bc}}$ & $110.3^{\mathrm{cd}}$ & $12.5^{b}$ \\
\hline Wh B & $2.6^{\mathrm{ad}}$ & $37.4^{c}$ & $7.9 c$ & $78.8^{\mathrm{d}}$ & $11.45^{b}$ \\
\hline $\mathrm{Wh} C$ & $5.3^{\mathrm{a}}$ & $58.7^{\mathrm{bc}}$ & $8.9^{\mathrm{bc}}$ & $95.4^{\mathrm{cd}}$ & $11.65^{b}$ \\
\hline Wh D & $4.5^{\mathrm{ab}}$ & $68.8^{\mathrm{bc}}$ & $9.2^{\mathrm{bc}}$ & $162.7^{\mathrm{cd}}$ & $13.05^{\mathrm{b}}$ \\
\hline Be 3 & $1.1^{\mathrm{cd}}$ & $69.6^{\mathrm{bc}}$ & $8.5^{\mathrm{bc}}$ & $254.1^{\mathrm{b}}$ & $14.85^{b}$ \\
\hline Be 5 & $3.7^{\mathrm{ac}}$ & $74.5^{\mathrm{bc}}$ & $9.6^{\mathrm{bc}}$ & $164.1^{\text {cd }}$ & $13.25^{\mathrm{b}}$ \\
\hline $\mathrm{Br} 1$ & $1.3^{\mathrm{cd}}$ & $68.0^{\mathrm{bc}}$ & $10.5^{b}$ & $145.7^{\mathrm{cd}}$ & $14.25^{b}$ \\
\hline $\mathrm{Br} 2$ & $0.5^{\mathrm{d}}$ & $81.3^{b}$ & $10.6^{\mathrm{b}}$ & $183.2^{\mathrm{bc}}$ & $14.75^{b}$ \\
\hline Com 164 & $2.1^{\mathrm{bd}}$ & $61.2^{\mathrm{bc}}$ & $8.3^{c}$ & $154.9^{\mathrm{cd}}$ & $12.95^{b}$ \\
\hline Com 142 & $0.7^{\mathrm{d}}$ & $183.7^{\mathrm{a}}$ & $14.6^{\mathrm{a}}$ & $390.5^{\mathrm{a}}$ & $20.4^{\mathrm{a}}$ \\
\hline
\end{tabular}

a-d In columns, values without any common letter are significantly different ( $\mathrm{P} \leq 0.05)$ according to Student-Newman-Keuls' test. Wh, white pileus cuticle; Be, beige cap; Br, brown cap; Com, commercial. 
B and Com 164 (average value of $8.1 \mathrm{~cm}$ ). All other cardoncello mushroom tested isolates occupied, for the same feature, an intermediate position between the last two and $\mathrm{Br} 1$ and $\mathrm{Br} 2$. The major pileus diameter of the maximum sized basidioma (PDMaxSB) $(20.4 \mathrm{~cm})$ was observed in Com 142 (Table 4). As shown in Table 5, the highest value $(19.2 \mathrm{~cm})$ height of the maximum sized basidioma (HMaxSB) was registered for Com 142 which resulted significantly different from Wh B, Wh $\mathrm{C}$ and $\mathrm{Br} 2$, with an average of $13.2 \mathrm{~cm}$; intermediate height values were observed for all other considered isolates. Gill decurrence along the maximum sized basidioma stipe, $\mathrm{Br} 2$ with $1.6 \mathrm{~cm}$ occupied the last position; all the other isolates reached, on average, $3 \mathrm{~cm}$, except for Com 164 with $2.3 \mathrm{~cm}$ (Table 5).

The stipe length of the medium sized basidioma (SLMedSB) was higher in Com $142(7.0 \mathrm{~cm})$ and significantly different from that of $\mathrm{Br}$ 2 and Be 5 which reached $4.2 \mathrm{~cm}$. Intermediate values, without any significant difference, were reached, for the same feature, by the other tested isolates. The stipe length of the maximum sized basidioma (SLMaxSB) varied from a maximum of $8.8 \mathrm{~cm}$ and a minimum of 4.7 $\mathrm{cm}$ in Com 142 and $\mathrm{Br} 2$, respectively; values registered for the same parameter in all other isolates ranged from 7.8 to $5.4 \mathrm{~cm}$ with some significant differences. Stipe diameter of the medium sized basidioma (SDMedSB) reached the maximum value of $3.3 \mathrm{~cm}$ in Com 142, followed by Be $3(2.6 \mathrm{~cm}), \mathrm{Br} 1$ and Wh B which reached, on average, 1.7 $\mathrm{cm}$ while all other tested isolates exhibited values ranging from 1.8 to $2.3 \mathrm{~cm}$ (Table 5). Stipe diameter of maximum sized basidioma (SDMaxSB) touched, on average, $4.15 \mathrm{~cm}$ for Com 142 and Be 3 which distinguished themselves from other tested isolates.

Finally, concerning the morphological abnormalities of basidioma cap, Be 3 resulted more predisposed to marginal lobes occurrence (0.75) than all other isolates for which values ranging from 0 to 0.39 were calculated. On the other hand, Wh B resulted more affected by warts (1.5) in respect of other tested isolates which appeared immune (0) or very few affected (0.3-0.1) (Table 5).

\section{Discussion}

The positive effect, in terms of yield earliness, of a long exposition to low temperatures of substrate bags invaded by mycelium of cardon- cello mushroom was confirmed for all tested isolates. In fact, after this treatment, all isolates gave $90-95 \%$ of the yield in the first basidioma production. This aspect can be economically interesting if one considers that the same effect can be generally obtained with 1-2 months of refrigeration, exception for the commercial isolate $\mathrm{C} 38$, which vice versa does not show any earliness after this treatment (M. Castelluccio, personal communication, 2006). Total fresh basidioma yield of all white cap isolates, except for Wh B, was satisfactory and significantly major than those of other tested isolates but Be 5 , which gave more than $285.7 \mathrm{~g} \mathrm{~kg}^{-1}$. Differences emerged among tested isolates, under productivity profile, underline the necessity of continuing research of new cardoncello mushroom wild isolates and emphasize the importance of ex situ conservation of various dikaryotic mycelia of the fungus. Results, if compared to those of the specific bibliography (Ferri et al., 2007) or of a previous cultivation trial, accomplished with other cardoncello mushroom wild and commercial isolates in the same protected environment in fall-winter 2005 (De Gioia et al., 2007) and concluded at the second basidioma harvest, show that the above mentioned white isolates can be artificially cultivated with appreciable economic results. Furthermore, in Sicilia, P. eryngii var. elaeoselini Venturella, Zervakis and La Rocca, artificially cultivated along with $P$. eryngii var. ferulae and $P$. nebrodensis, gave in two basidioma harvests a maximum fresh basidioma yield of about $20-25 \%$ of initial substrate weight (Scandurra, 2011). Cap cuticle of basidiomata produced by $\mathrm{Br} 1$ and $\mathrm{Br} 2$ under the experimental greenhouse conditions resulted less maroon than in nature. Also the original white pileus surface of three of the white isolates resulted as a feature partially modifiable by environmental conditions and sporophore age and acquired an isabelline tint which is closer to alutaceous colour reported by Venturella et al. (2000) for cap cuticle of $P$. eryngii var. elaeoselini mature basidiomata growing in nature. Only Wh B, although less productive in respect of the other tested white cap cuticle isolates, produced, under the trial conditions, basidiomata with stable white cap cuticle. The fact that cardoncello mushroom sporophores with isabelline cap cuticle can be also found in nature seems to suggest the silence of melanin gene only in young basidiomata or in particular climatic or environmental conditions which, hypothetically, could occur in weather periods characterized by cloud absence and, consequently, long exposure to sun rays and pronounced temperature excursions.

An economically important trait of the white cardoncello mushroom

Table 5. Main basidioma morphological characteristics and sensitivity to wart and lobe appearance on pileus of tested Pleurotus eryngii isolates.

\begin{tabular}{|c|c|c|c|c|c|c|c|c|}
\hline & Height & Gill & Stip & ength & Pileus & lameter & Lobes on & Warts on \\
\hline Isolate & $\begin{array}{l}\text { Maximum } \\
\text { sized } \\
\text { basidioma } \\
(\mathrm{cm})\end{array}$ & $\begin{array}{c}\text { Maximum } \\
\text { sized } \\
\text { basidioma stipe } \\
(\mathrm{cm})\end{array}$ & $\begin{array}{l}\text { Medium } \\
\text { sized } \\
\text { basidioma } \\
(\mathrm{cm})\end{array}$ & $\begin{array}{l}\text { Maximum } \\
\text { sized } \\
\text { basidioma } \\
(\mathrm{cm})\end{array}$ & $\begin{array}{l}\text { Medium } \\
\text { sized } \\
\text { basidioma } \\
(\mathrm{cm})\end{array}$ & $\begin{array}{l}\text { Maximum } \\
\text { sized } \\
\text { basidioma } \\
\text { (cm) }\end{array}$ & Pileus margin & $\begin{array}{l}\text { Pileus upper } \\
\text { surface }\end{array}$ \\
\hline Wh A & $14.7^{\mathrm{ab}}$ & $3.3^{\mathrm{a}}$ & $4.8^{\mathrm{ab}}$ & $6.3^{\mathrm{bc}}$ & $1.8^{\mathrm{c}}$ & $2.5^{\mathrm{b}}$ & $0.33^{b}$ & $0.17^{\mathrm{b}}$ \\
\hline Wh B & $13.2^{\mathrm{b}}$ & $2.7^{\mathrm{a}}$ & $5.1^{\mathrm{ab}}$ & $5.6^{\mathrm{bc}}$ & $1.6^{\mathrm{c}}$ & $2.1^{\mathrm{b}}$ & $0.00^{\mathrm{b}}$ & $0.33^{b}$ \\
\hline Wh C & $13.9^{b}$ & $2.6^{\mathrm{a}}$ & $5.7^{\mathrm{ab}}$ & $7.1^{\mathrm{ac}}$ & $1.9 \mathrm{bc}$ & $2.5^{\mathrm{b}}$ & $0.00^{\mathrm{b}}$ & $0.11^{b}$ \\
\hline Wh D & $16.2^{2 \mathrm{ab}}$ & $3.2^{\mathrm{a}}$ & $4.4^{\mathrm{b}}$ & $5.7^{\mathrm{bc}}$ & $2.3^{\mathrm{bc}}$ & $3.0^{\mathrm{b}}$ & $0.33^{b}$ & $1.50^{\mathrm{a}}$ \\
\hline Be 3 & $15.0^{a b}$ & $3.0^{\mathrm{a}}$ & $4.8^{\mathrm{ab}}$ & $7.3^{\mathrm{ab}}$ & $2.6^{\mathrm{b}}$ & $4.1^{\mathrm{a}}$ & $0.75^{\mathrm{a}}$ & $0.00^{\mathrm{b}}$ \\
\hline Be 5 & $14.1^{a b}$ & $2.7^{\mathrm{a}}$ & $4.2^{\mathrm{b}}$ & $5.4^{\mathrm{bc}}$ & $2.2^{\mathrm{bc}}$ & $2.9^{\mathrm{b}}$ & $0.00^{\mathrm{b}}$ & $0.11^{\mathrm{b}}$ \\
\hline Br 1 & $16.8^{8 \mathrm{~b}}$ & $3.3^{\mathrm{a}}$ & $6.2^{\mathrm{ab}}$ & $7.8^{\mathrm{ab}}$ & $1.7^{\mathrm{c}}$ & $2.3^{\mathrm{b}}$ & $0.25^{\mathrm{b}}$ & $0.00^{\mathrm{b}}$ \\
\hline $\mathrm{Br} 2$ & $12.6^{\mathrm{b}}$ & $1.6^{\mathrm{b}}$ & $4.2^{\mathrm{b}}$ & $4.7^{c}$ & $2.1^{\mathrm{bc}}$ & $2.8^{\mathrm{b}}$ & $0.39^{a b}$ & $0.00^{\mathrm{b}}$ \\
\hline Com 142 & $19.2^{\mathrm{a}}$ & $2.8^{\mathrm{a}}$ & $7.0^{\mathrm{a}}$ & $8.8^{\mathrm{a}}$ & $3.3^{\mathrm{a}}$ & $4.2^{\mathrm{a}}$ & $0.00^{\mathrm{b}}$ & $0.00^{\mathrm{b}}$ \\
\hline Com 164 & $14.7^{\mathrm{ab}}$ & $2.3^{\mathrm{ab}}$ & $5.3^{\mathrm{ab}}$ & $6.9^{a c}$ & $1.9 \mathrm{bc}$ & $2.8^{\mathrm{b}}$ & $0.19^{b}$ & $0.50^{\mathrm{b}}$ \\
\hline
\end{tabular}

${ }^{\mathrm{a}-\mathrm{c}}$ In columns, values without any common letter are significantly different ( $\left.\mathrm{P} \leq 0.05\right)$ according to Student Newman-Keuls' test. Wh, white pileus cuticle; Be, beige cap; Br, brown cap; Com, commercial. 
isolates, noticed in preliminary panel tests, seems the minor flesh hardness which renders their basidiomata more tender and thus, easily to cook and masticate. This feature could enlarge the number of $c a r$ doncello mushroom consumers who, from ever, appreciate its taste and in kitchen versatility. Into the next future, a well planned panel test of differently cooked $P$. eryngii basidiomata with white, beige and brown cap, along with a large market investigation, could contribute to a major diffusion of this fungus both in Italy and abroad.

\section{References}

AA.VV., 1998. Coltivazione ed avversità del Pleurotus eryngii - Speciale fungo cardoncello. Agric. Ricerca 176:41-96.

AA.VV., 2000. Atti del Convegno Nazionale Coltivazione ed avversità del fungo cardoncello (Pleurotus eryngii). Agric. Ricerca 188:39-144.

Camele I, Altieri L, Rana GL, 2010. Prima segnalazione di due basidiomiceti contaminanti il substrato di coltivazione di Pleurotus eryngii. Micol. Italiana 3:14-9.

De Gioia T, Sisto D, Rana GL, Figliuolo G, 2005. Genetic structure of the Pleurotus eryngii species-complex. Mycol. Res. 109:71-80.

De Gioia T, Figliuolo G, Rana GL, Sisto D, 2007. Confronto morfoproduttivo tra alcuni ceppi selvatici e commerciali di Pleurotus eryngii (D.C.: Fr.) Quél. in coltura protetta. Micol. Italiana 36:35-46.

Fermor TR, 1986. Bacterial diseases of edible mushrooms and their control. pp 361-370 in Proc. Int. Symp., Scientific and Technical Aspects of Cultivation of Edible Fungi, Pennsylvania State University, PA, USA.

Ferri F, 1985. Bacterial disease in fungi of the genus Pleurotus. Mush. Inf. 2:47-54.

Ferri F, 1986. I funghi - Micologia, isolamento, coltivazione. Edagricole, Bologna, Italy.

Ferri F, Zjalic S, Reverberi M, Fabbri AA, Fanelli C, 2007. I funghi Coltivazione e proprietà medicinali. Edagricole, Bologna, Italy.

Fletcher JT, White PF, Gaze RH, 1989. Mushrooms pest and disease control. Intercept, Andover, UK.

Hibbett DS, Binder M, Bischoff JF, Blackwell M, Cannon PF, Eriksson OE, Huhndorf S, James T, Kirk PM, Mclaughlin DJ, Powell MJ, Redhead S, Schoch CL, Spatafora JW, Stalpers JA, Vilgalys R, Aime MC, Aptroot A, Bauer R, Begerow D, Benny GL, Castelbury LA, Crous PW, Dai Y-C, Gams W, Geiser DM, Griffit GW, Gueidan C, Hawksworth DL, Hestmark G, Hosaka K, Humber RA, Hyde KD, Ironside JE, Koljag U, Kurtzman CP, Larsson K-H, Lichtward R, Longcore J, Miadlikowska J, Miller A, Moncalvo J-M, Mozley-
Standridge S, Oberwinkler F, Parmasto E, Reeb V, Rogers JD, Roux C, Ryvarden L, Sampaio JP, Schubler A, Sugiyama J, Thorn RG, Tibell L, Untereiner WA, Walker C, Wang Z, Weir A, Weiss M, White MM, Winka K, Yao Y-J, Zhang N, 2007. A higher-level phylogenetic classification of the Fungi. Mycol. Res. 111:509-47.

Iacobellis NS, 2011. Recent advances on bacterial diseases of cultivated mushrooms. In: J.M. Savoie, M. Foulogne-Oriol, M. Largeteau and G. Barroso (eds.) Proc. 7th Int. Conf. on Mushroom Biology and Mushroom Products (ICMBMB), Arcachon, France, 4-7 October 2011, INRA, Bordeaux, France, 1:457-465.

Iacobellis NS, Lavermicocca P, 1990. Batteriosi del cardoncello: aspetti eziologici e prospettive di lotta. Professione Agricoltore 2:32-3.

Iacobellis NS, Lo Cantore P, 1997. Bacterial diseases of cultivated mushrooms in southern Italy. pp 33-37 in Proc. 10th Congr. Medit. Phytopath. Union, 1-5 June 1997, Société Francaise de Phytopathologie, Montpellier - Lec Corum, France.

Iacobellis NS, Lo Cantore P, 1998. Recenti acquisizioni sul determinismo della batteriosi del cardoncello (Pleurotus eryngii). Agric. Ricerca 176:51-4.

Mang SM, Figliuolo G, 2010. Species delimitation in Pleurotus eryngii species-complex inferred from ITS and EF-1 gene sequences. Mycology 1:269-80.

Marras F, Sisto D, 1998. Selezione di nuovi ceppi di Pleurotus eryngii DC.: Fr. (Quél.) e P. nebrodensis Inzenga, in Sardegna e Puglia. Agric. Ricerca 176:43-6.

Rodrigues Estrada EA, Gasco-Jimenez M del M, Royse JD, 2010. Pleurotus eryngii species complex: Sequence analysis and phylogeny based on partial EF1 and RPB2 genes. Fungal Biology 114:421-8.

Scandurra S, 2011. I Pleurotus delle Umbelliferae. R.d.M. 4:291-315.

Sisto D, Faggiano S, Mannerucci F, 1998. Nuovi substrati per la coltivazione del cardoncello. Agric. Ricerca 176:47-50.

Venturella G, 2000. Typification of Pleurotus nebrodensis. Mycotaxon 75:229-31.

Venturella G, Zervakis G, La Rocca S, 2000. Pleurotus eryngii var. elaeoselini var. nov. From Sicily. Mycotaxon 76:419-27.

Venturella G, Zervakis G, Saitta A, 2002. Pleurotus eryngii var. thapsiae var. nov. from Sicily. Mycotaxon 81:69-74.

Zervakis G, Venturella G, 1998. Towards the elucidation of the systematics of the Pleurotus taxa growing on Umbellifers. In: Proc. Sixth Intern. Mycol. Congr. (abstract), Jerusalem, Israel.

Zervakis G, Balis C, 1996. A pluralistic approach on the study of Pleurotus species, with emphasis on compatibility and physiology of the European morphotaxa. Mycol. Res. 100:717-31. 